\title{
The Correlation Between Microsatellite Instability and the Features of Sporadic Colorectal Cancer in Sample of Iraqi Patients
}

\author{
Basim Mohammed Hanon ${ }^{1}$, Nidhal Abd Al-Mohaimen Mohammad ${ }^{2}$ and \\ Aqeel Shakir Mahmood ${ }^{3}$. \\ 1 Department of Microbiology, College of Medicine, Al-Nahrain University, Baghdad, Iraq \\ basimdr28@yahoo.com \\ ${ }^{2}$ Department of Microbiology, College of Medicine, Al-Nahrain University, department od medical biotechnology \\ ,college of applied biotechnology, Baghdad, Iraq \\ dr.nidhalmohammed@yahoo.com \\ ${ }^{3}$ Baghdad university -college of medicine ,Baghdad, Iraq, Chairman of the Scientific Council of gastrointestinal \\ surgery at the Iraqi Council for Medical Specialties \\ aqeel.shakir@yahoo.com
}

\begin{abstract}
Microsatillite instability (MSI) is a mutational signature found in colorectal carcinoma (CRC), it represents about $12 \%$ in non inherited CRC. We aimed in this study to correlate between MSI and sporadic CRC Iraqi patients. A total of 47 patients with colorectal carcinoma were enrolled in this study, among these patients $26(55 \%)$ males and $21(45 \%)$ females, with a range age from 37 years to 72 years, mean age (54.5 year). Microsatellite marker amplifications were performed as singleplex PCR reactions. Results were divided into three groups, group 1 with MSI high were constituted a frequency of $17 \quad(36.17 \%)$, and group 2 with MSS (16) (34.04\%) and group 3 with MSI low the frequency( 14 ) (29.78\%). MSI high was expressed in high percentage $(38.09 \%)$ in women comparted with male $34.61 \%)$, while its relation to age, results indicated that age group ( $\leq 50$ years) showed high percentage $(37.93 \%)$ compated with Group 1 ( $\geq 50$ years) (33.33\% ) and the realtion of MSI with morphological feature of the specimens showed that poorly diffrrentiated CRC specimens showed the highly percentage ( $47.07 \%$ ) when comparted with well and moderatly differntiated cases. The mucinous type of CRC reveled $100 \%$ pecentage for MSI comparted with nonmucinous (27.65\%) with siganficant difference. High frequancy of MSI was shown in right site (52.94\%) with significant difference compared with MSI L and MSS. In conclusion: This study showed that there were a close association between MSI with female patients, old patients, and right site, mucinous and poorly differentiated CRC.
\end{abstract}

\section{Indexing terms/Keywords}

CRC, MSI, PCR.

\section{Academic Discipline And Sub-Disciplines}

Immunogenetics.

\section{Subject Classification}

Tumor Immunology.

\section{Type (Method/Approach)}

PCR-Experimental.

\section{Council for Innovative Research}

\author{
Peer Review Research Publishing System
}

\section{Journal: JOURNAL OF ADVANCES IN BIOTECHNOLOGY}

Vol .4, No 1.

www.ciribt.org , jbteditor@gmail.com 


\section{INTRODUCTION}

Colorectal cancer (CRC), is one of the most frequent malignancies in the Western world. Worldwide, approximately 1,2 million people developed colorectal cancer in 2008 and the disease related mortality was about $36 \%$ (1) (2) The disease affects slightly more men than women and sporadic colon cancer is considered to be a disease of the elderly with a median age at diagnosis of 70 years (3).

Microsatellites are repeated DNA sequences, usually 1 to 10 nucleotides long, present throughout the genome. Instability is mostly characterized by single base-pair insertions or deletions in these repeat loci, causing widespread genomic instability due to the failure of the cell's mismatch repair (MMR) mechanism (4) (5) .A recognizable clinicopathological profile of MSI tumors has been established from clinical studies. CRC displaying MSI tend to be right sided and diagnosed at lower pathological stages compared with MSS cancers. The age distribution of MSI cancers follows a $u$ shaped distribution, and sporadic MSI cases are generally diagnosed in older patients ( $>70$ years of age) whereas familial cases are younger $(<50$ years of age)(6). Since many colon cancers demonstrate frame shift mutations at a small percentage of microsatellite repeats, the designation of a colon tumor as showing microsatellite instability depends on the detection of at least two unstable loci out of five from a panel of loci that were selected by a National Cancer Institute consensus conference (4).

MSI is also found in $\sim 80 \%$ of adenomas of variable size from HNPCC patients, compared to12-18\% of the sporadic tumors (7). MSI tumors are more often located in the proximal colon, poorly differentiated, and of a mucinous, or signet ring, histological type (8).Another common finding in MSI CRC is the presence of tumor-infiltrating T cells (9). MSI tumors have often been associated with a better patient prognosis compared with MSS (1). Three classes of MSI have been defined: MSI-H (MSI-high), MSI-L (MSI-low) and MSS (microsatellite stable) that are distinguished by the degree of instability found in a panel of five reference markers. The panel recommended by the National Cancer Institute consists of two mononucleotide (BAT25 and BAT26) and three dinucleotide (D5S346, D2S123 and D17S250) repeating units. MSI-H tumors exhibit instability in two or more markers whilst MSI-L tumors have instability in only one marker. Tumors lacking apparent instability can, however, be either MSI-L or MSS and so may require the analysis of additional markers for confirmation (4). This study aims to identify for the first time in Iraq, types of MSI in sample of CRC Iraqi patients.

\section{Aterial And Methods}

Specimens, were collected from GIT center, Baghdad hospital and private hospitals. In the period from 1-4-2013 to 1-22014, which more than three biopsies were obtained from grossly tumor areas, and surgery specimens obtain after surgery tumor removal both specimens from surgery and biopsies were fixed with $10 \%$ buffered formalinized saline, for preparation the paraffin embedded tissue blocks to histological molecular diagnostic methods DNA extraction from FFEP.

Histological evaluation specimens, slides from fixed paraffin embedded tissue blocks were stained with haematoxylin eosin stain and subsequently evaluated by an experienced pathologist.

DNA extraction from FFPF ,QIAamp DNA FFPE tissue kit, (50) reaction Mineute columns, kits. DNA evaluation by Nano drop For an A260/A280 value of 1.5, the percentage of protein in the DNA preparation, for good PCR-SSP results, DNA is required with an A260/A280 quotient of 1.6 or greater. The sections of tumor tissue should contain more than $50 \%$ of neoplastic cells (14) in order to avoid false negatives. Microsatellite marker amplifications are performed as singleplex PCR reactions using DNA from tumor tissue. In accordance to the recommendations by the NCI. The validated five microsatellite panel is tested first. This latter panel is currently adopted by the institutions of the IMPACTS group in a diagnostic setting (6)

\section{PCR PreMixAccuPower ${ }^{\circledR}$}

Stability: the powerful technology for convenient and easy to perform DNA amplification. It contains DNA polymerase, dNTPs, a tracking dye and reaction buffer in a premixed format, freeze-dried into a pellet. 25/100 bp Mixed DNA Ladder is specially designed for determining the size of double strand DNA from 25 to 2,000 base pairs. The DNA Ladder consists of 17 double strand DNA fragments ranging in size from 25 to $200 \mathrm{bp}$ in $25 \mathrm{bp}$ increments, the PCR reaction was performed in a final volume of $50 \mathrm{ml}$, containing:

$0.5 \mu \mathrm{lb}$-globin both forward primer, reverse primer $30 \mathrm{pmol} / \mathrm{ml} . \quad 0.3 \mathrm{pmol} / \mu \mathrm{l}$ final, $1 \mu \mathrm{l}$ of diluted sample DNA, $20 \mu \mathrm{mister}$ $\mathrm{mix}, \mathrm{H} 2 \mathrm{O}$ to volume, Overlay the reaction mixture with $20 \mathrm{ml}$ of mineral oil.

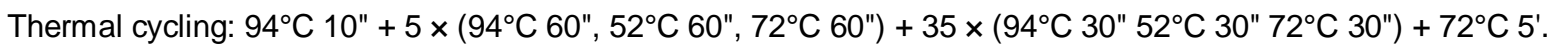

Gel visualization: mix $10 \mathrm{ml}$ of PCR product with $2 \mu \mathrm{l}$ of $6 \times$ loading buffer; load on a $2 \%$ agarose gel prepared with $1 \times$ TBE containing $0.5 \mathrm{mg} / \mathrm{ml}$ ethidium bromide. Run at $80 \mathrm{~V}$ constant until bromophenol blue reaches $1 / 2$ of the gel. Inspect under a UV source. A single band should be visible in the sample.

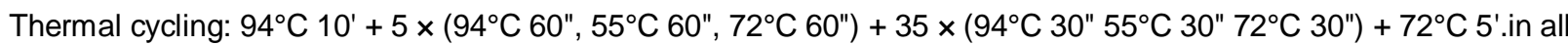
genes with same add of PCR reaction of b-globin.

\section{Internal control}

Since DNA extracted from FFPE can be variably degraded and may contain PCR inhibitors, we suggest performing a preliminary quality control to test if sample. DNA is suitable for MSI and to determine the optimal quantity for amplification. For this purpose, a $167 \mathrm{bp}$ fragment of the b-globin gene is amplified. Since b-globin gene is present in all the cells (it 
never undergoes deletions) and is not polymorphic, it is a suitable target for the control PCR.(15) The size of the amplified fragment (167 bp) reflects the length of the largest PCR product that can be obtained.

Positive control for b-globin: DNA from normal human lymphocytes, $50 \mathrm{ng} / \mathrm{ml} .(16)$

\section{PCR primers}

Primers: Lyophilized primers should be dissolved in a small volume of distilled water or to make a concentrated (e.g. $300 \mathrm{pmol} / \mu \mathrm{l}) \mathrm{stock}$ solution. Prepare small aliquots of working solutions containing $30 \mathrm{pmol} / \mathrm{ml}$ to avoid repeated thawing and freezing.

\begin{tabular}{|c|c|c|c|c|}
\hline Marker Name & $\begin{array}{c}\text { Genomic } \\
\text { Position }\end{array}$ & Sequences (5c-3c) & $\boldsymbol{T}^{\circ} \mathbf{m}$ & (bp) \\
\hline & & F: ACACAACTGTGTTCACTAGC & 53.4 & 167 \\
b-globin & 11 p15.5 & R: GAAAATAGACCAATAGGCAG & 53.9 & \\
\hline
\end{tabular}

\begin{tabular}{|c|c|c|c|c|}
\hline Marker Name & $\begin{array}{l}\text { Genomic } \\
\text { Position }\end{array}$ & Sequences $(5 c-3 c)$ & $T^{\circ} \mathrm{m}$ & (bp) \\
\hline D2S123 & 2p16-2p16 & $\begin{array}{l}\text { F: ACATTGCTGGAAGTTCTGGC } \\
\text { R: CCTTTCTGACTTGGATACCA }\end{array}$ & $\begin{array}{l}62.6 \\
57.5\end{array}$ & $121-141$ \\
\hline D5S346 & $5 q 21-5 q 22$ & $\begin{array}{c}\text { F: ACTCACTCTAGTGATAAATCGGG } \\
\text { R: AGCAGATAAGACAGTATTACTAGTT }\end{array}$ & $\begin{array}{l}58.7 \\
52.1\end{array}$ & $96-122$ \\
\hline D17S250 & $17 q 11.2-17 q 12$ & $\begin{array}{c}\text { F: GGAAGAATCAAATAGACAAT } \\
\text { R: GCTGGCCATATATATATTTAAACC }\end{array}$ & $\begin{array}{l}50.6 \\
57.2\end{array}$ & $151-169$ \\
\hline BAT25 & $4 q 12-4 q 12$ & $\begin{array}{l}\text { F: TCGCCTCCAAGAATGTAAGT } \\
\text { R: TCTGCATTTTAACTATGGCTC }\end{array}$ & $\begin{array}{l}59.7 \\
57.0\end{array}$ & 124 \\
\hline BAT26 & $2 p 16.3-2 p 16.3$ & $\begin{array}{l}\text { F: TGACTACTTTTGACTTCAGCC } \\
\text { R: AACCATTCAACATTTTTAACCC }\end{array}$ & $\begin{array}{c}57 . \\
59.0\end{array}$ & 121 \\
\hline
\end{tabular}

\section{Statistical methods}

The significance of differences in proportions was analyzed by the chi-square test. Fisher's exact test was used when there was a cell with a number less than 5 . Entry of data into the computer and the chi-square and Fisher exact tests were performed with SPSS version 15 and $P$ values equal or less than 0.05 were considered statistically significant.

\section{Results}

\section{Sex and age distribution}

Total of 47 patients with colorectal carcinoma were collected among of these patients $26(55 \%)$ males and $21(45 \%)$ females figure (1), with a range age from 37 years to 72 years, mean age (54.5 year), with 1:1.2 ratio between female and male. The patients' age were classified into two group first $50 \geq$ years $(38.29 \%)$, second group $50 \leq$ years $29(61.70 \%)$ fig. (2). 


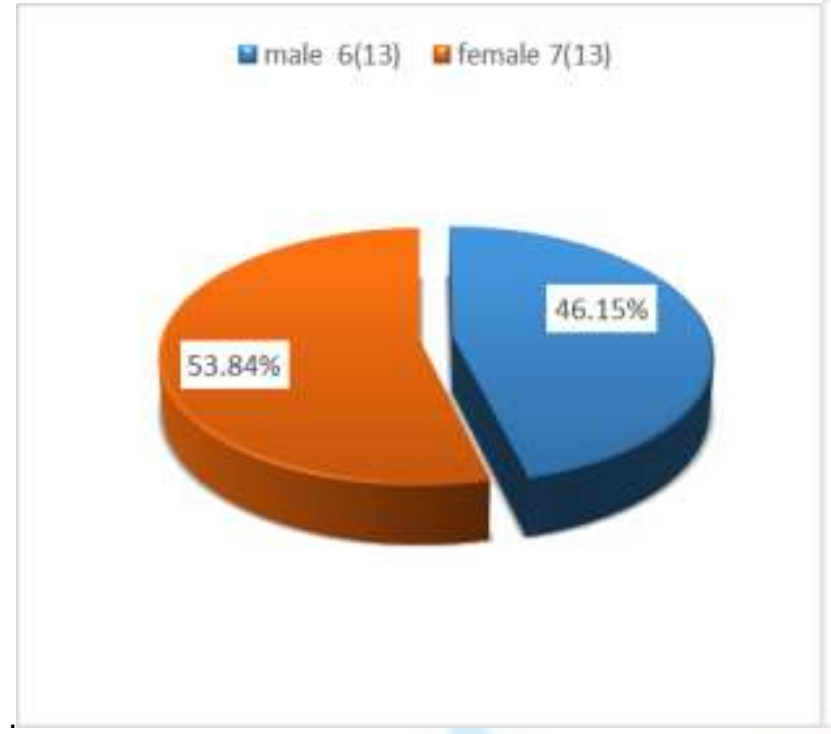

Figure 1. The sex distribution of CRC
- group 1502 aroup 2505

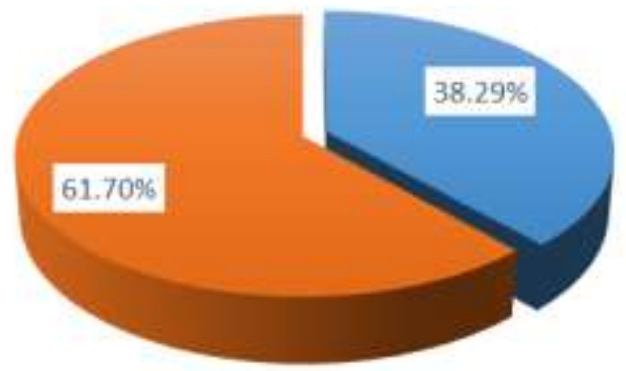

Figure 2 the age group frequency in CRC

Morphological differentiation, as regards with grades of colorectal carcinoma, it was observed that $(14.89 \%)$ cases of well differentiated, (53.19\%), moderate differentiated and (53.19\%), and (31.91\%) poorly differentiated Figure 3.

Site of tumor: Patients with CRC were classified according to the site of tumor location as shown in figure (4), right site consistent (51.06\%) of all cases and patients, with left site $(36.17 \%)$ and $(12.76 \%)$ in the rectum from all cases.

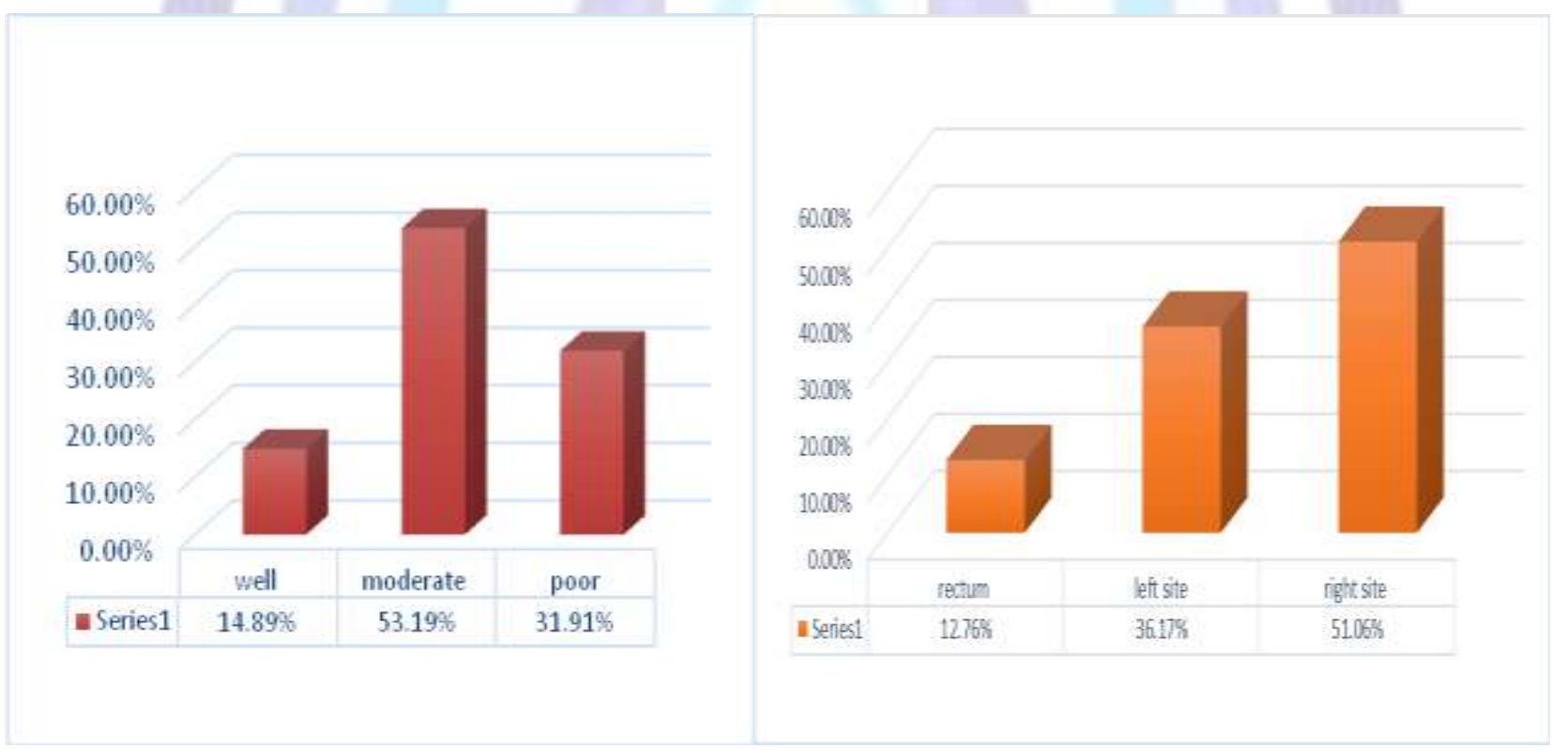

Figure 3. The morphological distribution of CRC

Figure4. Site of tumor distribution in CRC.

\section{MSI Distributions}

Microsatellite marker amplifications were performed as singleplex PCR reactions. The results were divided in to three groups, group 1 with MSI high were constituted a frequency of $17 \quad$ (36.17\%), and group 2 with MSS (16) (34.04\%) and group 3 with $\mathrm{MSI}_{\text {low }}$ the frequency( 14 ) (29.78\%) figure.5.

As shown in the figure 6, the internal control B-globin was appeared in the region 167bp while D5S346 reviled at the region 122 bp figure 7, BAT26 in 121bp figure 8, BAT25 in 124 bp figure 9, D17S250 in 169bp figure 10 and D2S123 in $141 \mathrm{bp}$ figure 11.

\section{MSI Related With Frequency of Microsatellite Panel Genes.}

$\mathrm{MSI}$ high and $\mathrm{MSI}$ low showed close associated with frequency of the microsatellite genes panel in all cases, the highly percentage was show in BAT25 48.93\%, while 44.68\% in both BAT26, D5S346, $19.14 \%$ in D17S250 and $25.23 \%$ in D2S123 12(47) table 1. 
ISSN 2348-6201

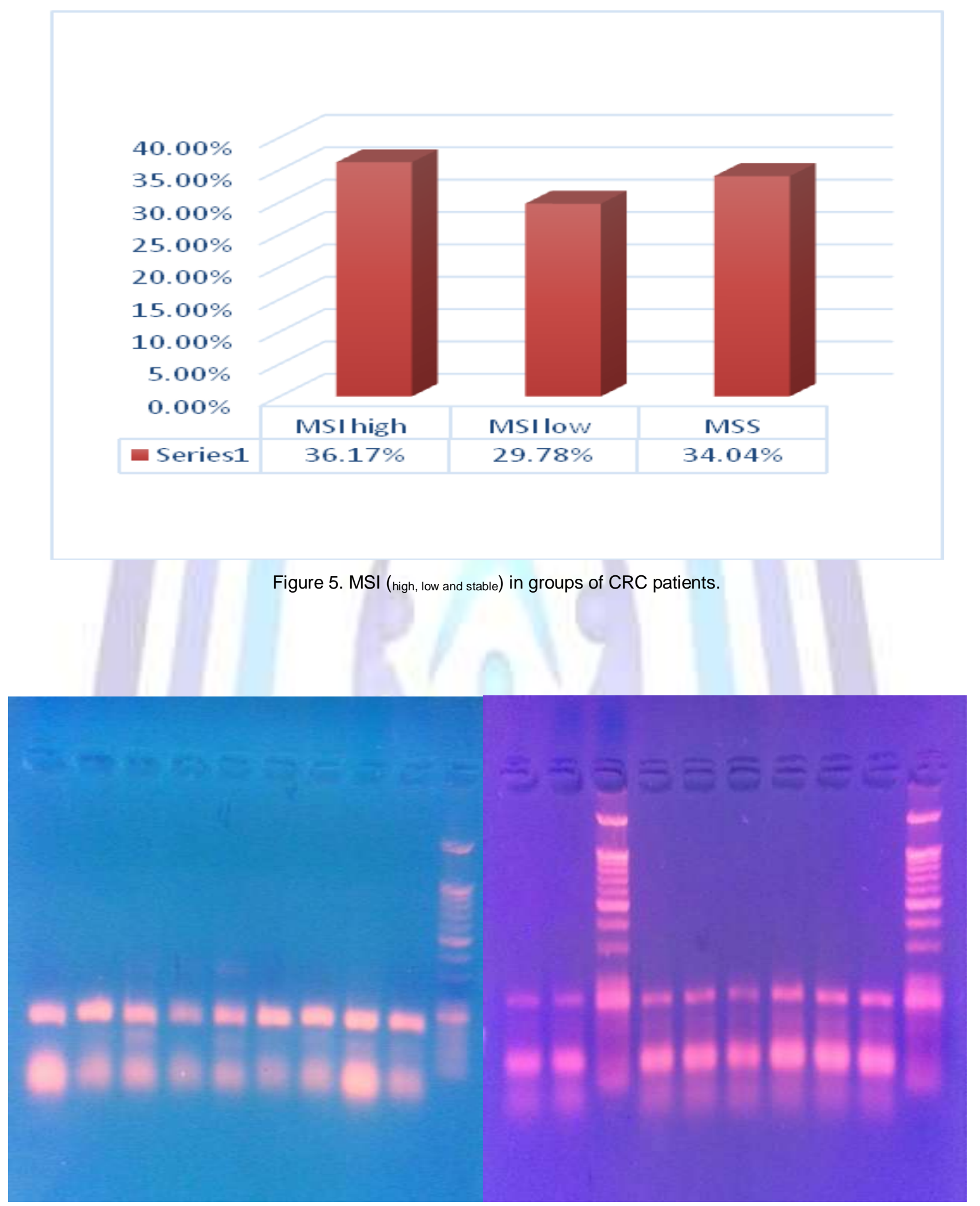

Fig. $7 \mathrm{Gel}$ electrophoresis ( $2 \%$ agarose, $7 \mathrm{v} / \mathrm{cm}^{2}, 1$. hrs) of PCR positive products for D5S346 was appeared in $122 \mathrm{bp}$, 25/100bp DNA ladder was used.
Fig. 6 Gel electrophoresis ( $2 \%$ agarose, $7 \mathrm{v} / \mathrm{cm}^{2}, 1$. hrs) of PCR positive products for b-globin 167bp , 25/100bp. DNA ladder was used 


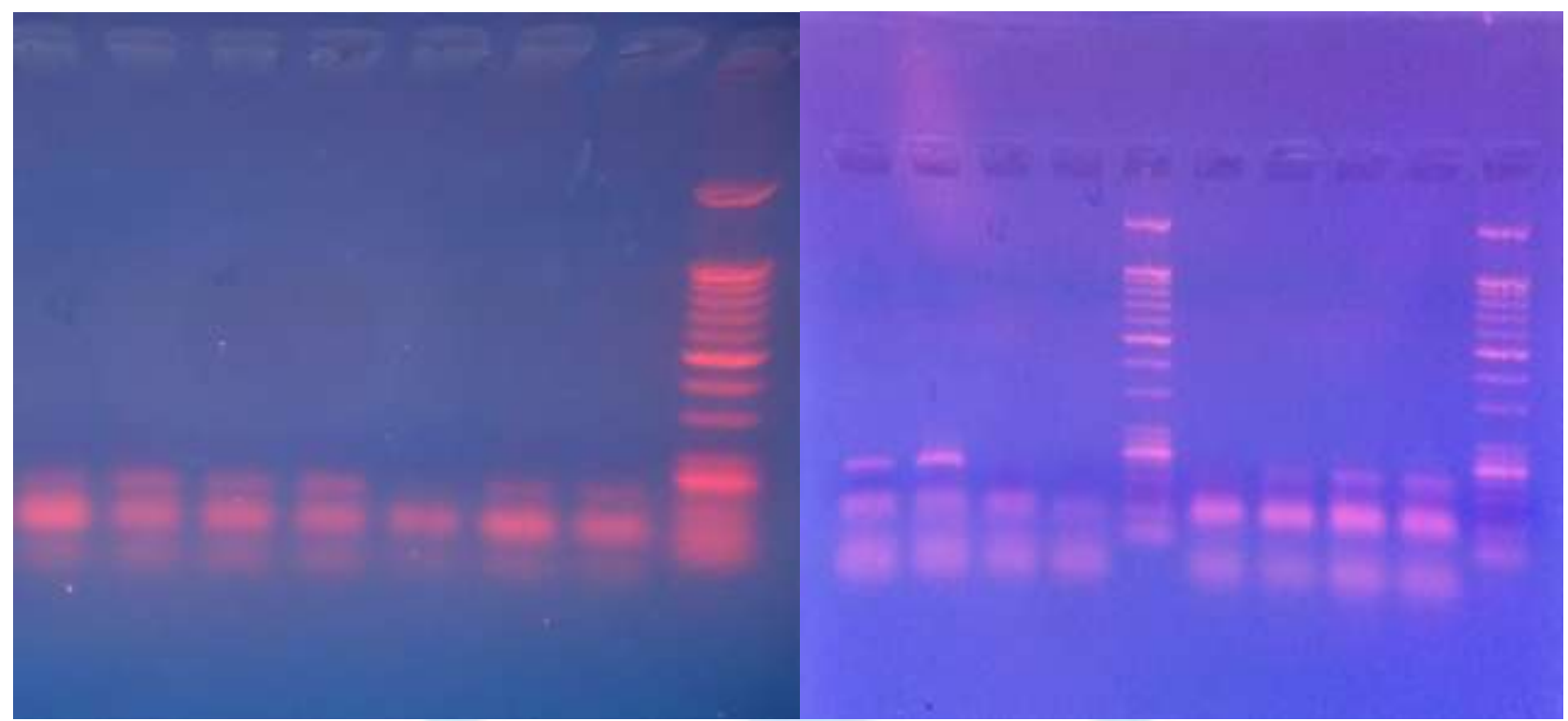

Fig. 9 Gel electrophoresis ( $2 \%$ agarose, $7 \mathrm{v} / \mathrm{cm}^{2}, 1$. hrs) of PCR positive products for BAT25 was shown in 124bp, 25/100bp DNA ladder was used
Fig. 8 Gel electrophoresis ( $2 \%$ agarose, $7 \mathrm{v} / \mathrm{cm}^{2}, 1$. hrs) of $\mathrm{PCR}$ positive products for BAT26 was shown in $121 \mathrm{bp}$ 25/100bp DNA ladder was used.

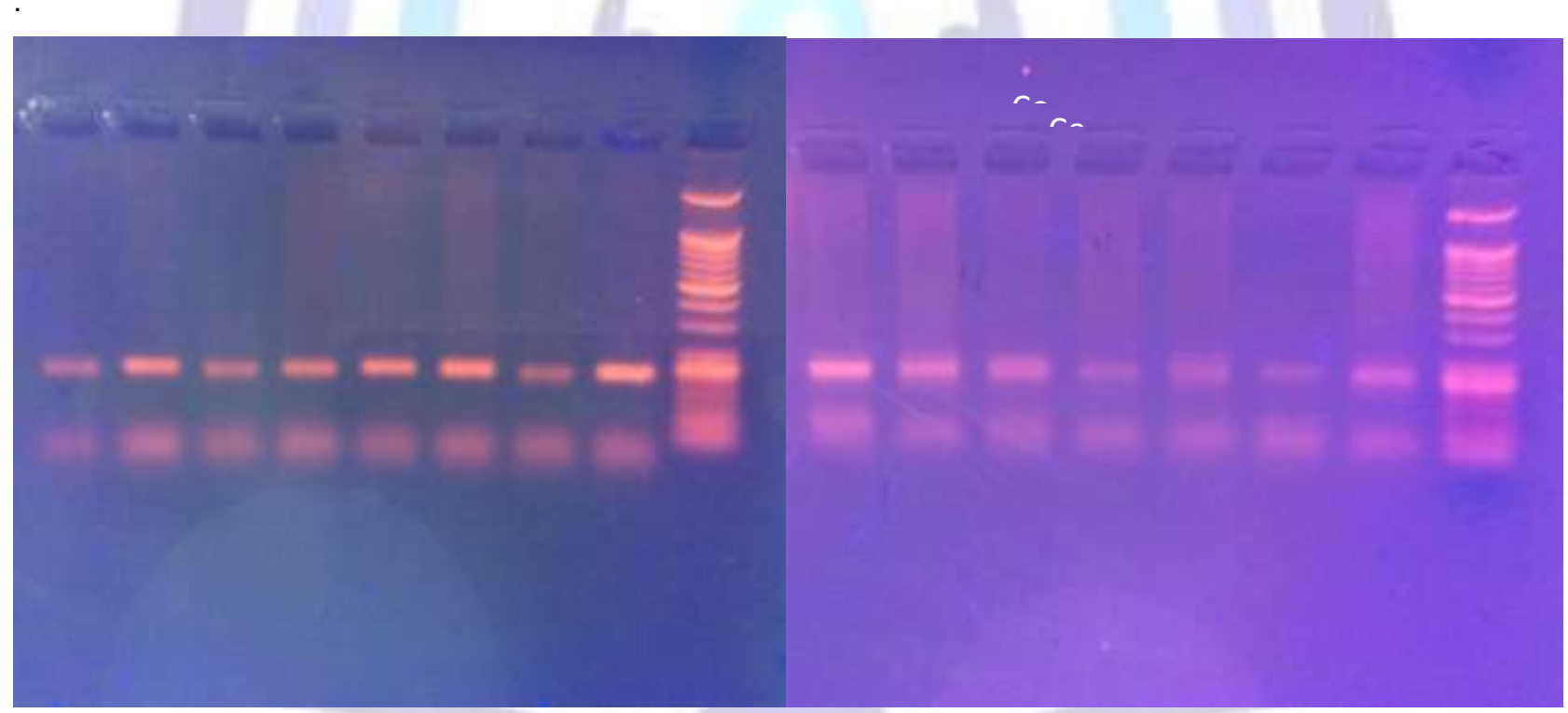

Fig. 11 Gel electrophoresis ( $2 \%$ agarose, $7 \mathrm{v} / \mathrm{cm}^{2}, 1$. hrs) of PCR positive products for D2S123 was shown in $141 \mathrm{bp}$, 25/100bp DNA ladder was used.
Fig. 10 Gel electrophoresis ( $2 \%$ agarose, $7 \mathrm{v} / \mathrm{cm}^{2}, 1 . \mathrm{hrs}$ ) of PCR positive products for D17S250 was shown in 169, 25/100bp DNA ladder was used 
Table 1 the Genes Fraquancy of Microsetillte Panle in Both MSI High and MSI Low

\begin{tabular}{|r|l|l|l|l|l|l|l|}
\hline NO & \multicolumn{1}{|c|}{ MSI status } & $\begin{array}{r}\text { Total } \\
\text { NO/\% }\end{array}$ & $\begin{array}{r}\text { MSI } \text { high } \\
\text { NO/\% }\end{array}$ & $\begin{array}{r}\text { MSI low } \\
\text { NO/\% }\end{array}$ & $\begin{array}{r}\text { MSS } \\
\text { NO/\% }\end{array}$ & $\begin{array}{c}\text { All } \\
\text { cases }\end{array}$ & $P$ value \\
\hline 1. & BAT26 & $21(44.68)$ & $17(36.17)$ & $4(8.51)$ & $26(55.31)$ & 47 & $P 0.0004$ \\
\hline 2. & BAT25 & $23(48.93)$ & $17(36.17)$ & $6(12.76)$ & $24(51.06)$ & 47 & 0.005 \\
\hline 3. & D5S346 & $21(44.68)$ & $17(36.17)$ & $4(8.51)$ & $26(55.31)$ & 47 & $P 0.0004$ \\
\hline 4. & D17S250 & $9(19.14)$ & $9(19.14)$ & $0(0)$ & $38(80.85)$ & 47 & $P 0.000$ \\
\hline 5. & D2S123 & $12(25.53)$ & $12(25.53)$ & $0(0)$ & $35(74.46)$ & 47 & $P 0.0000$ \\
\hline
\end{tabular}

MSI related with sex, $\mathrm{MSI}$ high was signifcantly associated with female patients that constut $38.09 \%$, while male patients account to $34.61 \%$ while, but male patients showed the high percentage $34.61 \%$ for expression of MSI low. Mss was shown to be expressed in high percentage in female patients $38.09 \%$ Table 4-2, but wih no signaficant defferent.

Table 2 The Sex Distribution in MSI ${ }_{\text {High, }}$ MSI Low $_{\text {and MSS. }}$

\begin{tabular}{|c|c|c|c|c|c|c|}
\hline Sex & $\begin{array}{c}\text { MSI } \text { high } \\
\text { NO/\%. }\end{array}$ & $\begin{array}{c}\text { MSI low } \\
\text { NO/\%. }\end{array}$ & $\begin{array}{c}\text { MSS } \\
\text { NO/\%. }\end{array}$ & $\begin{array}{c}\text { Total } \\
\text { number }\end{array}$ & P value & $\begin{array}{c}\mathbf{X}^{2} \\
\text { Df=2 }\end{array}$ \\
\hline Male & $9(34.61)$ & $9(34.61)$ & $8(30.76)$ & 26 & 0.944 & 0.115 \\
\hline Female & $8(38.09)$ & $5(23.80)$ & $8(38.09)$ & 21 & 0.526 & 1.286 \\
\hline P- & 0.732 & 0.131 & 1.000 & 47 & $D f=2$ \\
\hline
\end{tabular}

\section{MSI Associated With Age}

Patients were classified according to age in tow groups, Group 1which included patients with age less than 50 years was showed high percentage of expression for MSI low 38.33\%, , followed by the MSI high (33.33\%). The group 2 high associated with MSI high and MSS with $37.93 \%$, table 4-3 with no significant different.

\section{Table 3 MSI Associated with Age Group Patients of CRC}

\begin{tabular}{|l|l|l|l|l|l|}
\hline Age group & $\begin{array}{l}\text { MSI } \\
\text { NO/\% }\end{array}$ & $\begin{array}{l}\text { MSI low } \\
\text { NO/\%. }\end{array}$ & $\begin{array}{l}\text { MSS } \\
\text { NO/\%. }\end{array}$ & Total & X2= 1.213 \\
\hline Group 1 $\geq 50$ & $6(33.33)$ & $7(38.88)$ & $5(27.77)$ & 18 & \\
\hline Group 2 $\leq 50$ & $11(37.93)$ & $7(24.13)$ & $11(37.93)$ & 29 & \\
\hline & 17 & 14 & 16 & 47 & $P=0.5452$ \\
\hline
\end{tabular}

MSI related with morphological feature, MSI ${ }_{\text {high }}$ showed close associated with poorly defferentated cases $47.07 \%$, followed by moderatly defferentated $35.26 \%$ and the showed well deffrrentated $17.64 \%$ table $4-4$ but no signifacant deffernce between grade and MSI high and low and signaficant with MSS. 
Table 4 Morphological Distribuation in MSI ${ }_{\text {High, }}$ MSI Low $_{\text {La }}$ and in CRC.

\begin{tabular}{|c|c|c|c|c|c|c|}
\hline Grade & $\begin{array}{c}\text { MSI } \\
\text { No/\% }\end{array}$ & $\begin{array}{c}\text { MSI low } \\
\text { NO/\% }\end{array}$ & $\begin{array}{c}\text { MSS } \\
\text { No/\% }\end{array}$ & Total & P value & $\begin{array}{c}\mathbf{X}^{2} \\
\text { Df=2 }\end{array}$ \\
\hline well & $3(17.64)$ & $2(14.28)$ & $2(12.5)$ & 7 & 0.807 & 0.429 \\
\hline modreate & $6(35.26)$ & $7(50)$ & $12(75)$ & 25 & 0.156 & 3.720 \\
\hline poor & $8(47.05)$ & $5(35.17)$ & $2(12.5)$ & 15 & 0.067 & 5.400 \\
\hline P. & 0.187 & 0.131 & 0.0001 & & & 0.214 \\
\hline $\mathbf{X}^{2}$ & 3.353 & 4.071 & 18.750 & & $\mathrm{Df}=4$ & 5.807 \\
\hline
\end{tabular}

MSI related with muosinous and nonmuosinous CRC, MSI close association with mucinous cases of CRC showed high percentage of expression $100 \%$, comparted with nonmucinous AC with $27.65 \%$ Figure $4-12$, with highly significant drffrence.

Figure 4-12. MSI related with Muosinous and nonmuosinous CRC.

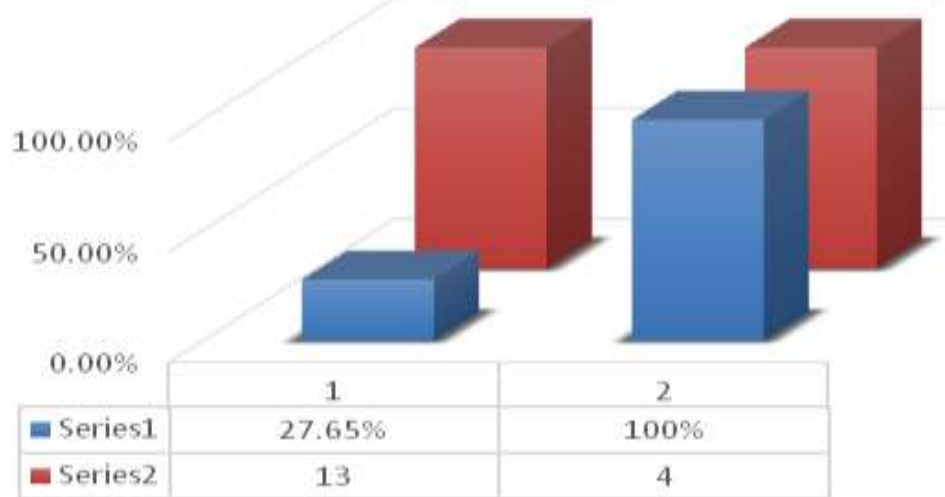

MSI related with site of tumor, $\mathrm{MSI}_{\text {high }}$ was highly expressed in patients with right site colon location (52.94\%), followed by left site (35.29\%) where an rectum showed lower expression site frequency percentage (11.76\%), as show in table $4-5$, with significant deffrence in both $\mathrm{MSI}_{\text {high }}$ and $\mathrm{MSI}_{\text {low. }}$.

Table 5 Realted of Site of Tumor With MSI Low, MSI Low And MSS

\begin{tabular}{|c|c|c|c|c|c|c|}
\hline Site & MSI high & MSI low & MSS & Total & P value & $\mathbf{X}^{2}$ \\
\hline Right & $9(52.94)$ & $7(50)$ & $8(50)$ & 24 & 0.829 & 0.375 \\
\hline Left & $6(35.29)$ & $6(42.85)$ & $5(31.25)$ & 17 & 0.916 & 0.176 \\
\hline Rectum & $2(11.76)$ & $1(7.15)$ & $3(18.75)$ & 6 & 0.472 & 1.500 \\
\hline Df=2 & 17 & 14 & 16 & 47 & & \\
\hline P-value & 0.038 & 0.036 & 0.168 & & $\mathrm{Df}=4$ & \\
\hline $\mathbf{X}^{2}$ & 6.529 & 6.643 & 3.563 & & 0.893 & 1.111 \\
\hline
\end{tabular}


$\mathrm{MSI}_{\text {high }}$ repeated gene, $\mathrm{MSI}_{\text {high }}$ showed the expressed 4 genes in this panale high frequncy with $52.94 \%$ and follwing by 3 genes with $47.05 \%$, and 5 genes reveiled $17.64 \%$ figure $4-13$ with signiffcant defference $p=0.012$.

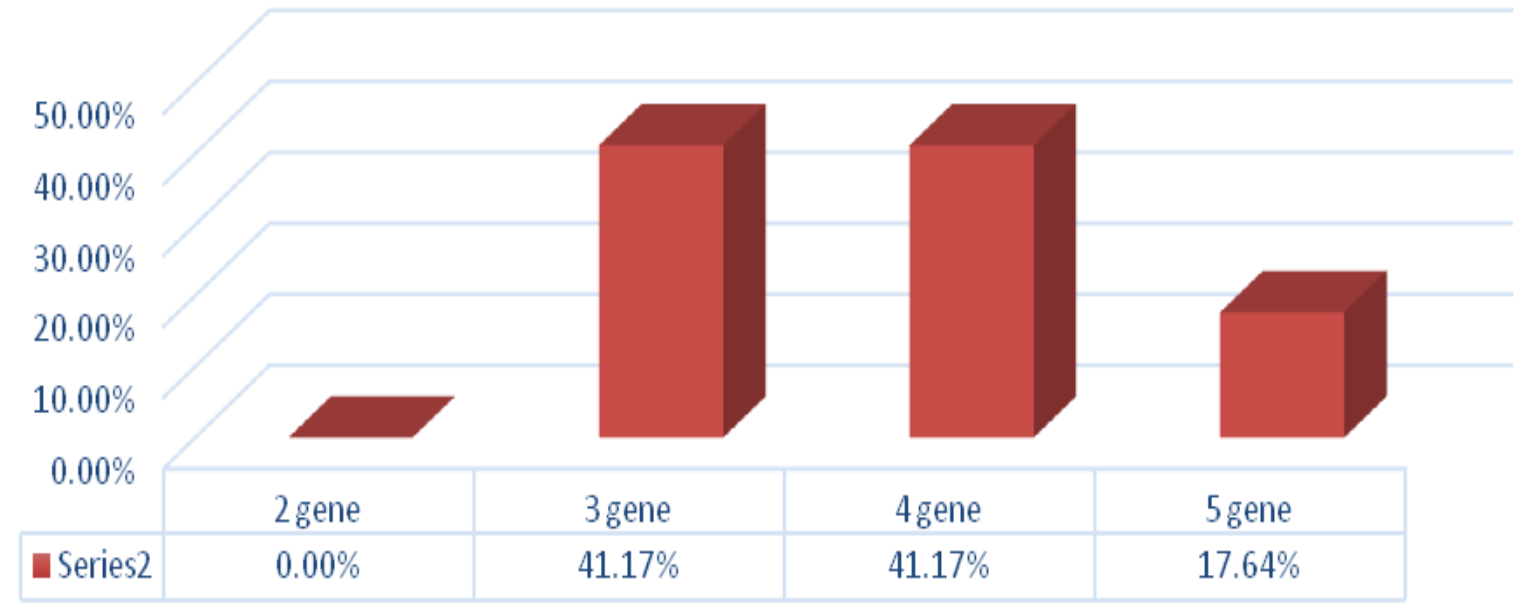

\section{Discussion}

Fig. 13. MSI ${ }^{\text {High }}$ Repeated Genes In Patient Of CRC.

MSI the hallmark of hereditary nonpolyposis colorectal cancer (HNPCC), previously known as Lynch syndrome, occurs in approximately $15-25 \%$ of sporadic tumors of the colorectum and other organs as well.(17)

$\mathrm{CRC}$ is a heterogeneous disease and MSI may serve as a predictive marker for the response of patients with CRC to specific therapies and as a guide to the selection of optimal therapy.(18)

In this study detection microsatellite colorectal cancer pathway, first MSI test 47 cases of tumor by used five microsatellite marker. The results divided in to three groups first $\mathrm{MSI}$ high with percentage $(36.17 \%)$, and second group $\mathrm{MSI}$ low was recorded in (29.78 \%), while the third group MSS was shown in (34.04\%).

This result was agreement with some and different from other, in study of,(29) was demonstrated (43\%) microsatellite instability-high (52.94\%) were microsatellite stable (MSS) and 2(3.9\%) were $\mathrm{MSH}_{\text {Low }}$.

MSI markers on paraffin-embedded surgically resected tissues sporadic Iranian colorectal cancer patients MSI analysis revealed MSI-H (26.9\%), MSI-L (16.4\%) and MSS (56.7\%) (20) while in study of (21) Microsatellite instability analysis showed (20.8\%), MSS 58.4\%, MSI-L 20.8\%.

While in the study of (22) by used same Bethesda panel of sporadic CRCs in Czech patients the rate of MSI (20.4\%), MSI $\mathrm{L}(3.9 \%)$ and MSS (72.1\%). in Italy patient with 10 markers used to detection MSI, the rate of $\mathrm{MSI} 25.0 \%, \mathrm{MSI} \mathrm{L} 29.5 \%$ and MSS $45.5 \%$ In study of, (23) .

Some studies was shown less rate of MSI, in study of (24) the prevalence of MSI of sporadic CRC cases was $17 \%$, and that of MSS was (83\%), while in study of (25) was show MSI (14.73\%), MSI L (8.21\%) and MSS (77.05\%) but in study of 756 patients from Omani patients were referred to (12.2\%) the rate of $\mathrm{MSI}-\mathrm{H}(26)$ In study (29) the rate of $\mathrm{MSI}-\mathrm{H}(17.97 \%)$, MSI-L (12.58\%) and MSS (68.53\%).

Tumor classification is historically based on various clinical (eg, proximal versus distal), pathological (eg, mucinous versus nonmucinous; well-moderate versus poorly differentiated), and/or molecular features [eg, microsatellite instability status (MSI)-high versus microsatellite stable (MSS) (28) (29) (30)

This study close associated with female, old patients, right site, mucinous and poorly differentiation, because small number of patients some criteria appeared high percentage but not significant. According to the criteria, the results of current study was apperaed, MSI high in the femal high percentage $38.09 \%$ comparted with male $34.61 \%$, while the relation with age group the Group $2 \leq 50$ was shown high percentage $37.93 \%$ compated with Group $1 \geq 5033.33 \%$ and the realted of MSI with morphological feature was show the highly percentage in poor deffrrentated $47.07 \%$ comparted with well and moderate. The mucinous MSI was reveled highly 4(4) with $100 \%$ pecentage comparted with nonmucinous MSI $13(43)$ with $27.65 \%$ with siganficant defference. The site of tuomr with MSI was appeared high frequancy in right site $52.94 \%$ with significant difference compared with MSI L and MSS. 
This study agreement with (31) also observed this relationship when analyzed the location of tumors according to MSI status sporadic MSI are common in the proximal colon whereas MSI-L and MSS usually occur in the distal colon and the rectum, (20) (26) ( (32)

The MSI status was associated with right-sided location,(24). (33) (34) (35)

Significant relationships were seen between microsatellite instability, young and old age.(36) In microsatellite stable tumors observed significant relationships, increased age, (37)

Sporadic CRC with MSI-High molecular features have a distinct phenotype, they are more common in older women.(35)

MSI-H CRCs also tend to occur more frequently in female CRC patients and with earlier onset of disease $(<50$ years) $(35)$ while most patients in the MSI-H group were females (26) (20) CRC have a propensity to develop on in older women. (24) (34) Significant relationships were seen between microsatellite instability and female gender (36)

Significant relationships were seen between microsatellite instability poor histological differentiation and MSI CRCs tend to have prominent poor differentiation.(32) (36).(38). These features are found in both familial and sporadic MSI-H CRC cases occur predominantly in the poor differentiation related with MSI (11) (32) (37). (39) (40).

Mucinous CRC, a subtype of CRC, is characterized by the abundant production of extracellular mucins and accounts for $5-15 \%$ of all CRCs (41).

CRC have a propensity to develop in a mucinous phenotype (11) (32) (33) (34) (37) (39) (40). while significantly higher percentages of mucinous CRC had MSI or CIMP (24).(26).

Pathological characteristics include increased lymphocytic infiltration (Crohn's disease-like reaction),).(11) (32) 33) (39) (40).

The high frequency of MSI-H suggests that should look at microsatellite instability prior to chemotherapy to determine the most appropriate chemotherapeutic strategy in our population.

With regard to $\mathrm{MSI}$ status and CRC patient survival, a systematic review of 32 studies that reported survival data on a total of 7642 colorectal cancer patients, including 1277 with MSI-H tumors, showed that MSI-H tumors were associated with better prognosis compared with MSS tumors (42) however, accumulating evidence has been suggested that MSI-high tumors are associated with good prognosis (43) (37)

CRC patients with MSI-H CRC status have better prognosis compared to non-MSI tumors, particularly among young patients (11) (33) (40) (44),(45) (46)

\section{Molecular Correlates in CRC}

The role of MSI-L as a subtype of molecular changes in CRC is controversial and tumors showing it resemble MSS tumors in clinical features (11) (40) (47)

Similar to the MSI-H tumors, MSI-L tumors also tend to occur more commonly in proximal colon, but their gender and family history associations are more similar to the MSS tumors (48)

Whether MSI-low (MSI-L) exists as a distinct phenotype from MSS has been controversial (47) (49)

Thus, a newer MSI marker panel has been designed to separate a substantial number of MSI-L tumors into MSS and MSI$\mathrm{H}(49)(50)$

\section{MSI Related With Frequency of Microsatellite Panel Genes.}

In this study the frequency of the microsatellite genes panel in all cases, the high percentage was recorded in BAT25 $48.93 \%$, while both BAT26, D5S346 was shown in $44.68 \%$, while D17S250 was appeared in $19.14 \%$ and D2S123 in $25.23 \%$.

Among MSI-H patients, instability in BAT-25 occurred in (83.3\%), BAT 26 (72.2\%), D2S123 in (61.1\%) cases, D17S250 in $(61.1 \%)$, and D5S346 in (44.4\%).(20)

Samples positive for BAT25 instability (14\%), BAT26, (21\%) for BAT40, (18\%) for D2S123, (16\%) D17S250, and (14\%) for D5S346.(21)

\section{Refrences}

[1] Cunningham, D., Atkin, W., Lenz, H J., et al (2010). Colorectal cancer. Lancet 375:1030-47.

[2] Jemal, A., Bray, F., Center, MM., et al (2011). Global cancer statistics. CA Cancer J Clin, 2011.

[3] Van Steenbergen, LN., Elferink, MA., Krijnen, P. et al. (2010). Improved survival of colon cancer due to improved treatment and detection: a nation wide population-based study in The Netherlands 1989-2006. Ann Oncol; 21: 2206-2212.

[4] Weitz, J., Koch, M., Debus J, et al (2005). Colorectal cancer. Lancet 365(9454): 153-165.

[5] de la Chapelle, A. (2004). "Genetic predisposition to colorectal cancer." Nat Rev Cancer 4(10): 769-8. 
[6] Boland, CR. , Thibodeau, SN. , Hamilton, SR. et al. (1998). A National Cancer Institute Workshop on Microsatellite Instability for cancer detection and familial predisposition: development of international criteria for the determination of microsatellite instability in colorectal cancer. Cancer Res;58:5248-5257.

[7] Karran, P. (1996). Microsatellite instability and DNA mismatch repair in human cancer. Semin Cancer Biol;7:1524.

[8] Jiricny, J.(2006). The multifaceted mismatch-repair system. Nat Rev Mol Cell Biol;7(5):335-46.

[9] Poynter JN, Siegmund KD, Weisenberger DJ et al (2008) Molecular characterization of MSI-H colorectal cancer by MLHI promoter methylation, immunohistochemistry, and mismatch repair germline mutation screening. Cancer Epidemiol Biomark Prev 17:3208-3215.

[10] lino, H., Simms, L., Young, J., et al (2000). DNA microsatellite instability and mismatch repair protein loss in adenomas presenting in hereditary nonpolyposis colorectal cancer. Gut;47:37-42.

[11] Boland, CR. \& Goe,I A. (2010). Microsatellite instability in colorectal cancer. Gastroenterology 138(6): 20732087.e3

[12] Jass, JR. (2007). Classification of colorectal cancer based on correlation of clinical, morphological and molecular features. Histopathology. Jan;50(1):113-30.

[13] Guastadisegni C, Colafranceschi M, Ottini L, et al (2010). Microsatellite instability as a marker of prognosis and response to therapy: a meta-analysis of colorectal cancer . Eur J Cancer.Oct;46(15):2788-98.

[14] Aaltonen LA. , Salovaara R. , Kristo P. , et al (1998). Incidence of hereditary nonpolyposis colorectal cancer and the feasibility of molecular screening for the disease. N Engl J Med 338(21): 1481-1487.

[15] Saiki RK. , Gelfand DH. , Stoffel S. , et al (1988). Primer-directed enzymatic amplification of DNA with a thermostable DNA polymerase. Science 239(4839):487-491.

[16] Lothe RA. , Peltomaki P. , Meling Gl. , et al (1993). Genomic instability in colorectal cancer: relationship to clinicopathological variables and family history. Cancer Res 53(24):5849-5852.

[17] Peltomaki, P. (2003). Role of DNA mismatch repair defects in the pathogenesis of human cancer. J Clin Oncol;21(6):1174-9.

[18] Grady, WM and Carethers, JM. (2008). Genomic and epigenetic instability in colorectal cancer pathogenesis. Gastroenterology;135(4):1079-99.

[19] Ashktorab H. , Hassan Brim , Al-Riyami M. , et al (2008). Sporadic Colon Cancer: Mismatch Repair Immunohistochemistry and Microsatellite Instability in Omani Subjects. Dig Dis Sci 53:2723-2731.

[20] Moghbeli M., Moaven O. , Dadkhah E. , et al (2011). High frequency of microsatellite instability in sporadic colorectal cancer patients in Iran. Genet. Mol. Res. 10 (4): 3520-3529.

[21] Rasuck C. , Leite S. , Komatsuzaki F., et al (2012). Association between methylation in mismatch repair genes, V600E BRAF mutation and microsatellite instability in colorectal cancer patients. Mol Biol Rep (2012) 39:25532560.

[22] Vasovcak P., Pavlikova K. , Sedlacek Z. et al (2011) Molecular genetic analysis of 103 sporadic colorectal tumours in Czech patients. PLoS One 6:e24114.

[23] Agostini M. , Enzo MV. , Morandi L. et al (2010). A ten markers panel provides a more accurate and complete microsatellite instability analysis in mismatch repair-deficient colorectal tumors. Cancer Biomark 6:49-61.

[24] Tanaka H., Deng G. , Matsuzaki K. , et al (2006). BRAF mutation, CpG island methylator phenotype and microsatellite instability occur more frequently and concordantly in mucinous than non-mucinous colorectal cancer Int. J. Cancer: 118, 2765-2771.

[25] Ogino S., Kawasaki T., Kirkner G. et al., (2007). Evaluation of Markers for CpG Island Methylator Phenotype (CIMP) in Colorectal Cancer by a Large Population-Based Sample. Journal of Molecular Diagnostics, Vol. 9, No. 3 ,

[26] Ashktorab H. , Smoot D. , Farzanmehr H. , et al (2005). Clinicopathological features and microsatellite instability (MSI) in colorectal cancers from African Americans Int. J. Cancer: 116, 914-919.

[27] Ogino S., Odze RD., Kawasaki T., et al., (2006). Correlation of pathologic features with CpG island methylator phenotype (CIMP) by quantitative DNA methylation analysis in colorectal carcinoma. Am J SurgPathol, 30: 11751183.

[28] Hamilton S. and Aaltonen, LA. (2000). Pathology and genetics of tumours of digestive system., World Health Organisation: New York.

[29] Compton, C.C. (2003). Colorectal carcinoma: Diagnostic, prognostic, and molecular features. Modern Pathology,. 16(4): p. 376-388. 
[30] Redston, M. (2009). Epithelial Neoplasms of the Large Intestine. In: Odze RD \&Goldblum JR (eds) Surgical pathology of the GI tract, liver, Biliary tract, and pancreas. Philadelphia, 597-637.

[31] Stefanius K. (2011). Colorectal carcinogenesis via serrated route. Thesis PHD, University of Oulu, Faculty of Medicine.

[32] Jenkins MA. , Hayashi S. , O'Shea AM. , et al (2007). Pathology features in Bethesda guidelines predict colorectal cancer microsatellite instability: a populationbased study. Gastroenterology;133(1):48-56.

[33] Hawkins, NJ., Bariol, C., Ward, RL.(2002).The serrated neoplasia pathway. Pathology, 34: 548-555.

[34] Costello JF., and Plass C: Methylation matters. J Med Genet 38:285-303, 2001

[35] lacopetta B, Grieu F, Amanuel B.( 2010). Microsatellite instability in colorectal cancer. Asia Pac. J. Clin. Oncol.; 6: 260-9. 78.

[36] Samowitz WS. , Curtin K. , Ma KN. et al (2001) Microsatellite instability in sporadic colon cancer is associated with an improved prognosis at the population level. Cancer Epidemiol Biomarkers Prev 10:917-923.

[37] Samowitz W, Albertsen H, Herrick J, et al (2005). Evaluation of a large, population-based sample supports a CpG island methylator phenotype in colon cancer. Gastroenterology 129:837-845.

[38] Jass JR (2004). HNPCC and sporadic MSI-H colorectal cancer: a review of the morphological similarities and differences. Fam Cancer 3:93-100.

[39] Ruszkiewicz AR \& Jass JR (2004) Microsatellite Instability in Colorectal Cancer: What, How, When, and Why? Pathology Case Reviews 9(4): 163-172.

[40] Mäkinen MJ (2007) Colorectal serrated adenocarcinoma. Histopathology 50(1): 131-150.

[41] Secco GB. , Fardelli R. , Campora E. , et al (1994). Primary mucinous adenocarcinomas and signet-ring cell carcinomas of colon and rectum. Oncology;51:30-4.

[42] Popat, S., Hubner, R., Houlston, RS. (2005). Systematic review of microsatellite instability and colorectal cancer prognosis. J ClinOncol, 23: 609-618.

[43] Ward RL. , Cheong K. , Ku SL. , et al (2003). Adverse prognostic effect of methylation in colorectal cancer is reversed by microsatellite instability. J Clin Oncol 21:3729-3736.

[44] Barault L. , Charon-Barra C. , Jooste V. , et al (2008). Hypermethylator phenotype in sporadic colon cancer: study on a population-based series of 582 cases. Cancer Res 68:8541-8546.

[45] Gryfe R. , Kim H. , Hsieh ET. , et al (2000). Tumor microsatellite instability and clinical outcome in young patients with colorectal cancer. N Engl J Med;342(2):69-77.

[46] Wright CM. , Dent OF. , Barker M., et al (200). Prognostic significance of extensive microsatellite instability in sporadic clinicopathological stage C colorectal cancer. Br J Surg.;87(9):1197-202

[47] Tomlinson I. , Halford S. , Aaltonen L. , et al (2002). Does MSI-low exist? J Pathol 197(1): 6-13.

[48] Bapat B. , Lindor NM. , Baron J. , et al.(2009). The association of tumor microsatellite instability phenotype with family history of colorectal cancer. Cancer Epidemiol Biomarkers Prev;18(3):967-75.

[49] Bacher JW. , Flanagan LA. , Smalley RL. , et al (2004). Development of a fluorescent multiplex assay for detection of MSI-High tumors. Dis Markers, 20:237-250.

[50] Murphy KM. , Zhang S. , Geiger T. , et al (2006). Comparison of the microsatellite instability analysis system and the Bethesda panel for the determination of microsatellite instability in colorectal cancers. J Mol Diagn, 8:305311. 